governments and institutions led to positive and innovative development of law. One such delegation was a personal favorite of Jack's and deserves special mention. From 1990-1994 Jack was an indispensable member of the U.S. delegation to negotiations with the Soviet Union on the U.S.-Soviet maritime boundary, the longest maritime boundary in the world. His leadership in inter-agency deliberations and his creative legal solutions made invaluable and permanent contributions both to the agreement that was signed and the development of the law of maritime boundaries.

Whether on issues of war and peace or more mundane technical issues, Jack was unfailingly responsive, imaginative, thought, sound and dedicated to making sure the U.S. position was grounded in law and legal policy, no matter how intense the pressures. And even in the most pressured times, Jack retained a decency, warmth, understanding and sense of humor that added another aspect of comfort to the wise counsel he provided.

Several years ago, we both served on a Society panel which Jack moderated. That honor is matched again today by the chance to remember and enjoy again the glow of Jack's mind, with and wisdom. He served and serves as a model of what a fine international lawyer should be. We are proud to pay tribute to our esteemed colleague and beloved friend who was taken too soon from us. Even so, for Jack and his legacy, gone will not be forgotten.

\title{
TRIBUTE TO JOAQUiN TACSAN
}

A tribute to Joaquin Tacsan was then presented by Edwin Smith.

\section{SUMMARY OF PRESIDENT'S REPORT}

President Brower was not worried about the Society's programs, which have been very successful. In June 1996 the Society cosponsored in Mexico City a program on regionalism. The Society has been cooperating with the Canadian Council on International law, and President Brower addressed its meeting last fall. Another trilateral project, with Canada and Japan, is planned for 1998. Plans are well underway for the Fourth Hague Joint Conference with the Dutch Society of International Law, July 2-5, 1997. The Society is trying to educate the federal judiciary on international law, in a project headed by Jim Apple of the Federal Judicial Center, and is also trying to educate the U.S. Congress in a project headed by Peter Watson, the recent Chair of the International Trade Commission.

The Society is working with the State Department and the International Law Institute to continue publication of the Digest of United States Practice in International Law. Arthur Rovine will head the ASIL role. The International Law Institute will provide funding and people. The Society will perform a review function.

There are hopes for another joint meeting in Geneva next year with the Graduate Institute of International Studies.

For the time being, David Bederman will lead the Society's Panel on State Responsibility. The Panel continues to work on two books dealing with the Iran-United States Claims Tribunal.

By now, every one of the General Counsels of the international financial institutions based in Washington has made a breakfast presentation in that ongoing program. There have been other Tillar House briefings as well, including one on the ICJ Advisory Opinion on Nuclear Weapons. 